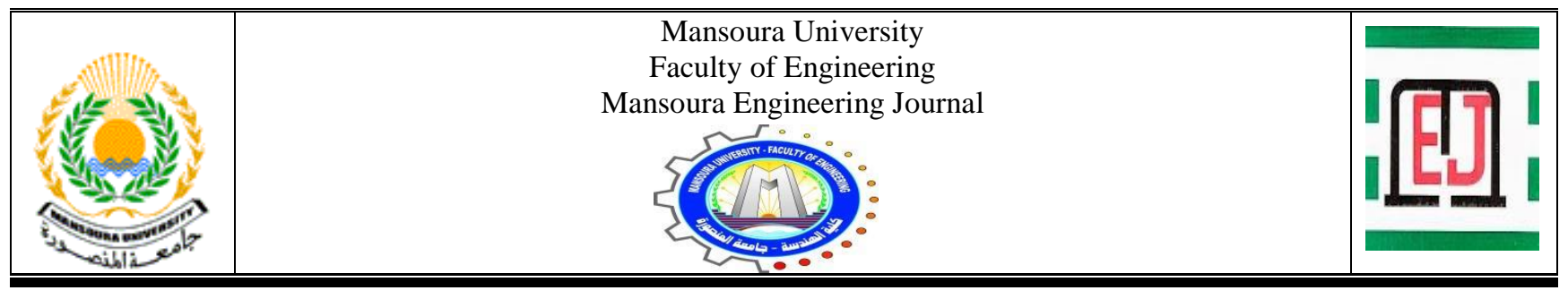

\title{
Adaptive Technologies of Nano-Architecture for the Next Generation of Sustainable Building Applications
}

\author{
Kassem S. El-Alfy, Mona A. El-Wazir and Aya M. Shalaby*
}

\begin{tabular}{|l|}
\hline KEYWORDS: \\
Nanotechnology, \\
Nano-Architecture, \\
Nanomaterials, \\
Nanomaterials \\
Techniques, Vacuum \\
insulation panels, \\
Aerogel, Phase change \\
material. \\
\\
\end{tabular}

Abstract - The present research casts light on the recent development in discovering a novelty in the field of technology which needs staying up with the latest updates with this innovation which has prompted nanotechnology. This has become the most important technology connected with our daily life and many activities and fields. The manufacture of many of the products on the market depends on nanotechnology, whereas the control of materials in the ultra-small-scale nanometer is a revolution in contemporary technology in all areas of life, especially in materials design, construction methods, and architectural perceptions. The research addresses the definition of nanotechnologies and their applications through the use of nanomaterials and applies them in the construction field, which led to a high evaluation of sustainable buildings that are compatible with the environment. The Specific Programs Building attached to the Faculty of Engineering at Mansoura University is selected as the case study where nano-insulation materials are applied to help improve the performance of the building and reduce the energy consumed, especially in building cooling operations.

\section{INTRODUCTION}

$\mathrm{T}$ THE expression "nanotechnology" has developed throughout the years by means of conceptual drift to the term "anything smaller than microtechnology," for example, nanopowders, and different things that are nanoscale in size, but not alluding to mechanisms that have been deliberately constructed from nanoscale components. This development version of the term is more properly called "Nanoscale Bulk Technology," whereas the original meaning is

Received: (28 September, 2020) - Revised: (10 January, 2021) - Accepted: (09 February, 2021)

Prof. Dr. Kassem Salah El-Alfy, Professor of Irrigation \& Hydraulic Engineering Department, Faculty of Engineering, Mansoura University. Dean of Mansoura Higher Institute for Engineering and Technology (e-mail: amrorana2003@yahoo.com).

Associate Prof. Mona Awad El-Wazir, Associate Professor of Architecture Department, Faculty of Engineering, Mansoura University. Vice Dean for Education and Student Affairs at the Nile Higher Institute of Engineering and Technology (e-mail: monaawad74@gmail.com).

*Corresponding Author: Eng. Aya Medhat Shalaby, Bachelor of Science, Architecture Department, Faculty of Engineering, Mansoura University (e-mail: arch.aya.medhat@gmail.com). presently more relevant to "Molecular Nanotechnology" (MNT), or "Nanoscale Engineering," or "Molecular Mechanics," or "Molecular Machine Systems," or "Molecular Manufacturing" ${ }^{[1]}$.

Nanotechnology is an energizing zone of logical improvement which guarantees more for less. It provides approaches to make smaller, less expensive, lighter and faster devices that can accomplish smarter and cleverer things, use less raw materials, and consume less energy. There are numerous models of nanotechnology application from simple to complex. For instance, nano-coatings are capable of repelling dirt, reducing the need for harmful cleaning agents, or preventing the spread of hospital-borne infections. Proceeding onward to more complicated products, a great example of the use of nanotechnology application is a cell phone, which has changed significantly within a few years getting to be smaller and smaller, while paradoxically, developing smarter and faster and less expensive ${ }^{[2]}$.

The uses of nanotechnology are in all fields of our life, it can relate in medicine, industry, communications, transportation, and more important, architecture. The utilization of nanotechnology in architecture is wide and varies from the early 
stages of sketching up to the final touches of finishing, particularly in picking the correct material which won't only reflect the design but also has a significant affects the method of architecture thinking according to the new colossal options that offered by nanotechnology ${ }^{[3]}$.

Nano-Architecture is the integration of nanotechnology into architecture, using nanoproducts, nanomaterials, nanotelecommunication, or even nanoshapes. When you insert new technology into a field such as the construction industry, one should in every case initially look at the advantages and benefits it can bring. In the case of using nanotechnology, we are talking about the added worth and extra functions according to the market requirements regarding product development. Great design on a fundamental level constantly depends on demand, and thusly contributes to the advancement of both nanomaterials and resulting nanoproduct, on the long haul the materials and products which required by demand will be established while others will vanish from the market ${ }^{[4]}$. Regardless of any factor, nanotechnology can make a concrete contribution to the following areas: ${ }^{[4]}$

- Optimization of existing products.

- Reduction in weight and/or volume.

- Reduction in the number of production stages.

- A more efficient use of materials.

- Reduced need for maintenance. And as a direct result:

- Reduction in the consumption of raw materials and energy and reduced $\mathrm{CO} 2$ emissions.

- Conservation of resources, greater economy, comfort.

\section{NANOMATERIALS TEChNIQUES}

Nanomaterials are a field which adopts a materials sciencebased strategy to nanotechnology. It studies materials with morphological highlights on the nanoscale, and particularly those which have unique properties coming from their nanoscale dimensions. Nanoscale is typically defined as smaller than a one-tenth of a micrometer in one dimension at least, however, this term is likewise utilized for materials smaller than one micrometer ${ }^{[5]}$. Table 1 shows nanomaterials in different dimensions.

TABLE 1

NANOMATERIALS CATEGORIZED BASED ON THEIR DIMENSIONS. Source: Nano material science, Nanotechnology, $(2010)^{[6]}$.

\begin{tabular}{c||c||c}
$\begin{array}{c}\text { Nanomaterial } \\
\text { Dimension }\end{array}$ & Nanomaterial type & Scale \\
\hline $\begin{array}{c}\text { One Dimensional } \\
(1-D)\end{array}$ & Thin Films. Coatings. & $<100 \mathrm{~nm}$ \\
\hline $\begin{array}{c}\text { Two Dimensional } \\
(2-D)\end{array}$ & Nanotubes. Fayers. Nanowires. & $<100 \mathrm{~nm}$ \\
\hline $\begin{array}{c}\text { Three } \\
\text { Dimensional (3-D) }\end{array}$ & $\begin{array}{c}\text { Nanoparticles. Nanorings. } \\
\text { Quantum Dots. Microcapsules. } \\
\text { Nanoshells. }\end{array}$ & $<100 \mathrm{~nm}$ \\
& \multicolumn{2}{c|}{}
\end{tabular}

\section{A. Coating (Finishing Materials)}

\section{1) Self-Cleaning (Lotus Effect)}

This is one of the best-known means of designing surfaces with nanomaterials. The name "Lotus-Effect" is often confused with "Easy-to-clean" surfaces or with Photocatalysis, which is also self-cleaning ${ }^{[8]}$. Fig. 1 shows natural self-cleaning for Lotus leave.
TABLE 2:

COATINGS TYPES []

\begin{tabular}{|c|c|c|c|}
\hline Product & $\begin{array}{l}\text { Self-Cleaning } \\
\text { (Lotus Effect) }\end{array}$ & $\begin{array}{c}\text { Self-Cleaning } \\
\text { (Photocatalysis) }\end{array}$ & $\begin{array}{c}\text { Easy to Clean } \\
\text { (ETC) }\end{array}$ \\
\hline Properties & $\begin{array}{l}\text { Hydrophobic } \\
\text { (water } \\
\text { trickles off). }\end{array}$ & $\begin{array}{l}\text { Hydrophilic surfaces. } \\
\text { Deposited dirt is } \\
\text { broken down and lies } \\
\text { loose on the surface. }\end{array}$ & $\begin{array}{l}\text { Hydrophobic } \\
\text { (water-repellent } \\
\text { and often also } \\
\text { oleophobic). } \\
\text { Surface } \\
\text { Repellence } \\
\text { without using the } \\
\text { Lotus-Effect. }\end{array}$ \\
\hline Specifications & $\begin{array}{l}\text { Microscopica } \\
\text { lly rough, not } \\
\text { smooth. } \\
\text { Well suited } \\
\text { for surfaces } \\
\text { that are } \\
\text { regularly } \\
\text { exposed to } \\
\text { sufficient } \\
\text { quantities of } \\
\text { water. }\end{array}$ & $\begin{array}{l}\text { A water film washes } \\
\text { dirt away. } \\
\text { UV light and water } \\
\text { are required. } \\
\text { Light transmissions } \\
\text { for glazing and } \\
\text { translucent } \\
\text { membranes } \\
\text { improved. are }\end{array}$ & $\begin{array}{l}\text { Smooth } \\
\text { surfaces with } \\
\text { reduced surface } \\
\text { attraction. } \\
\text { Surfaces have a } \\
\text { lower force of } \\
\text { surface } \\
\text { attraction due to } \\
\text { a decrease in } \\
\text { their surface } \\
\text { energy. }\end{array}$ \\
\hline Usage & $\begin{array}{l}\text { For better } \\
\text { optimal use } \\
\text { and low } \\
\text { maintenance } \\
\text { facades. }\end{array}$ & $\begin{array}{l}\text { Reduce the extent of } \\
\text { dirt adhesion on } \\
\text { surfaces. }\end{array}$ & $\begin{array}{l}\text { Are most } \\
\text { commonly found } \\
\text { in interiors, but } \\
\text { can also be } \\
\text { employed } \\
\text { outdoors for } \\
\text { better weather } \\
\text { protection. }\end{array}$ \\
\hline
\end{tabular}

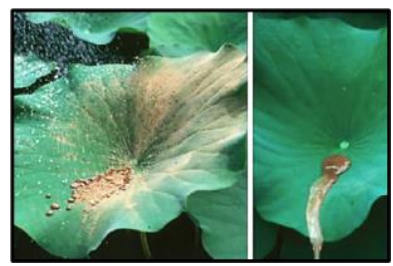

Fig.1. The Lotus Leaf with its natural self-cleaning "Lotus-Effect"

- Example for the use of the self-cleaning Lotus Effect: Ara Pacis Museum, Rome, Italy ${ }^{[10]}$, Fig. 2.
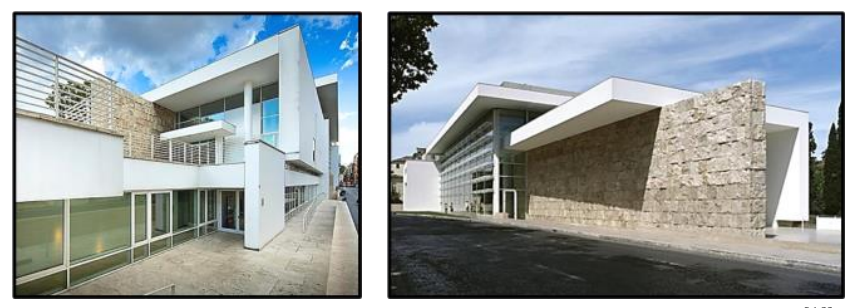

Fig. 2. Ara Pacis Museum exterior, showing Self-cleaning coating ${ }^{[10]}$.

2) Self-Cleaning (Photocatalysis)

Photocatalytic self-cleaning is probably the most widely used nano function in building construction. Its primary effect is that it greatly reduces the extent of dirt adhesion on surface. Generally, photocatalytic self-cleaning is a lowmaintenance and trouble-free solution ${ }^{[11]}$. See Fig. 3.

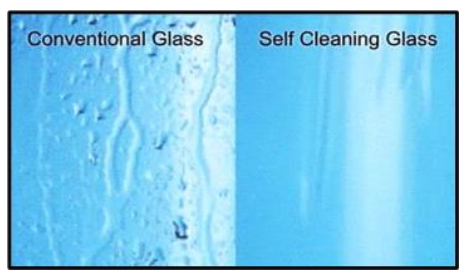
Fig. 3. Comparison of conventional and self-cleaning glasses.
(adapted from Pro Clean Window 2018) 
- Example for the use of the self-cleaning Photocatalysis: Muhammad Ali Center MAC, Louisville, USA ${ }^{[13]}$, Fig. 4.
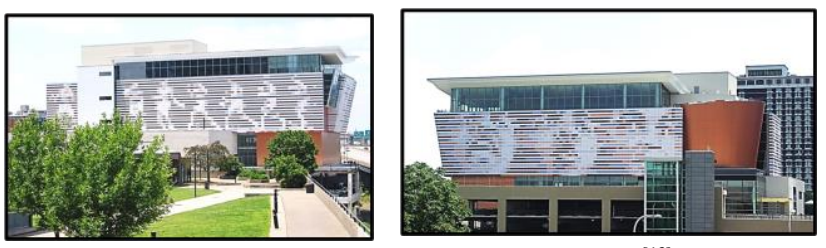

Fig. 4. Muhammad Ali Center MAC facades ${ }^{[13]}$.

3) Easy-to-clean (ETC)

Easy-to-clean surfaces are water repellent and smooth rather than rough with reduced surface attraction resulting in reduced surface adhesion. This causes water to be repelled, forming droplets, and running off. Easy-to-clean surfaces are therefore hydrophobic, i.e. water repellent, and often also oleophobic, i.e. oil repellent ${ }^{[14]}$. See Fig. 5.

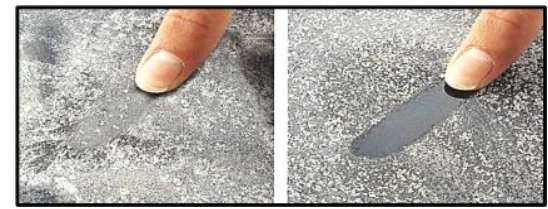

Fig. 5. Left without ETC coating, right with ETC coating ${ }^{[14]}$.

- Example for the use of the Easy-To-Clean (ETC): Science to Business Center Nanotronics \& Bio, Marl, Germany ${ }^{[14]}$, Fig. 6.
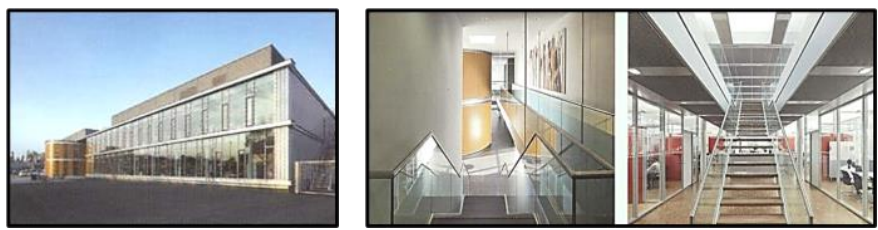

Fig. 6. Science to Business Center Nanotronics \& $\mathrm{Bio}^{[14]}$.

\section{B. Insulation (Energy Saving Materials)}

1) Thermal insulation (Vacuum insulation panels- VIPs) Vacuum insulation panels (VIPs) are ideally suited for providing very good thermal insulation with a much thinner insulation thickness than usual ${ }^{[15]}$. See Fig. 7.
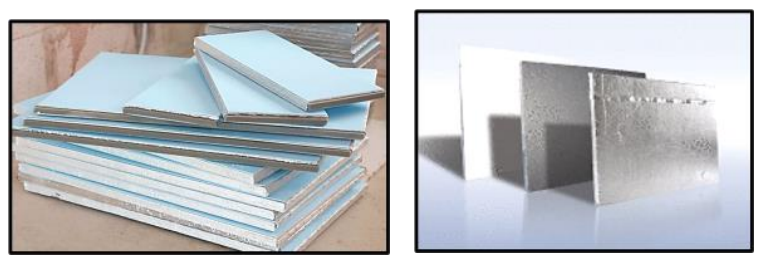

Fig. 7. Vacuum insulation panels with a protective encasement ${ }^{[15][16]}$.

- Example for the use of the Vacuum insulation panels (VIP): The Grand Tower, Frankfurt, Germany, Fig. 8.

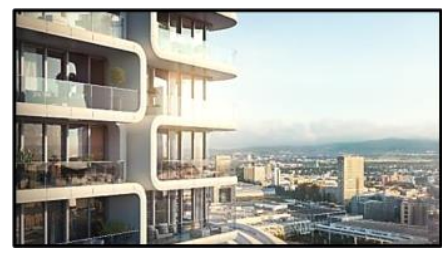

Fig. 8. VIP used in façade insulation (BRUSSELS, 9 November 2018)
2) Thermal insulation (Aerogel)

A product known as Nanogel, a form of aerogel, not only provides high performance thermal insulation but also effective sound insulation ${ }^{[17]}$. See Fig. 9.

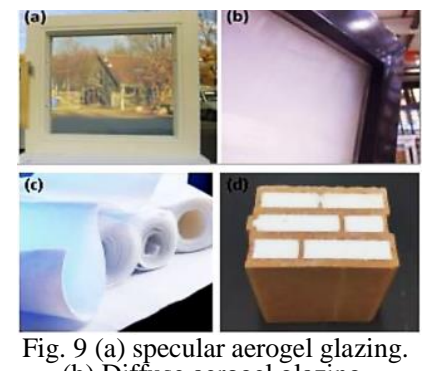

(b) Diffuse aerogel glazing.

(c) Aerogel as thermal insulation material (Aspen Aerogel Inc.)

(d) Brick with aerogel filling ${ }^{\mid 18\}}$

- Example for the use of the Aerogel:

Levanger primary school, Norway ${ }^{[18]}$, Fig. 10.

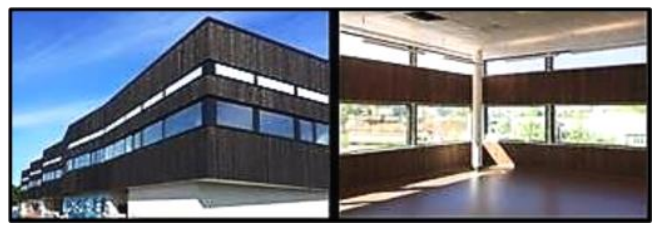

Fig. 10. Levanger primary school, Norway ${ }^{[18]}$.

3) Temperature regulation (Phase change material- PCMs) Correct use of PCMs can reduce peak heating and cooling loads, and may also allow for smaller dimensions of technical equipment for heating and cooling ${ }^{[19]}$. See Fig. 11.

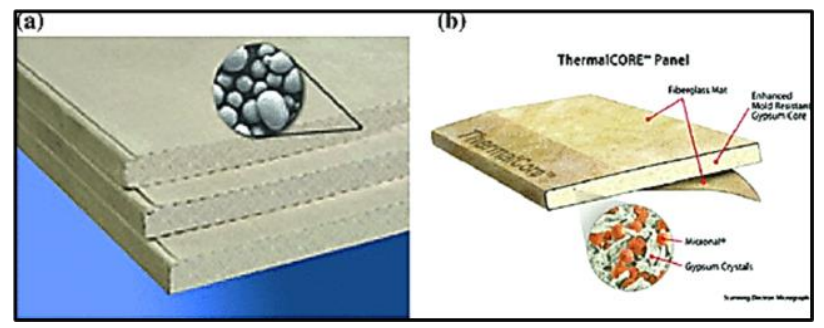

Fig. 11. (a) Gypsum wallboard with Micronal PCM (from BASF). (b) Thermal CORE phase change drywall (from National Gypsum) ${ }^{[19]}$.

- Example for the use of the Phase Change Material (PCMs): New Construction Training Center, Chula Vista, California, USA, Fig. 12.

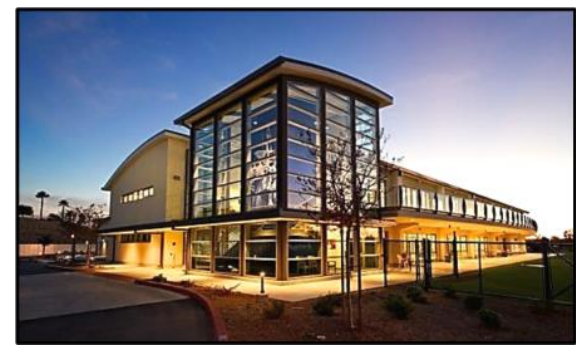

Fig. 12. Phase Change Material in New Construction Training Center (From Emerging Technologies Coordinating Council).

(b) Thermal CORE phase change drywall (from National Gypsum) ${ }^{[19]}$.

\section{NANOMATERIALS TYPES}

Nanoparticles can be classified into different types according to the size, morphology, chemical and physical properties. 
1) Nanoparticles for applications are already commercially available in a wide range of forms that can support a host of applications ${ }^{[20]}$.

2) Titanium dioxide ( $\mathrm{TiO} 2$ ), widely used in its anatase (one of the tetragonal forms of titanium dioxide, usually found as brown crystals, used as a pigment in paints and inks) ${ }^{[21]}$ form for photocatalytic applications (self-cleaning, antimicrobial) ${ }^{[21]}$.

3) Nanoparticles can also come in varying levels of treatments. Various Nanoparticles can be obtained that, for example, already have hydrophobic or hydrophilic properties useful in a wide range of applications ${ }^{[20]}$.

4) Carbon Nanotubes for applications are available in a wide variety of single-walled (SWNT) and multi-walled (MWNT) forms, including different lengths, diameters, and purities [20].

\section{The Problem}

Architecture practice faces a number of major environmental challenges that resulted in deficiencies in architectural building performance. This has affected society and the surrounding environment. It has required a search for modern technologies to achieve the environmental standards and requirements needed to build a clean and sustainable architectural environment that seeks to conserve environmental resources. Major problems include:

1) Increasing energy consumption rates through buildings' airconditioning operations in a way that is not commensurate

2) With the energy production rates.

3) Not using advanced technologies such as nanotechnology to improve the performance of the building and then preserve environmental resources.

4) Building performance analyses are commonly completed after the planning of the architectural and structural designs where the shortening of the constant sustainability analysis during the planning process prompts an ineffective process of retroactive modification to the design to accomplish a lot of performance criteria.

5) Hence the inability of the building to preserve the environment, achieve the concepts of sustainability, and provide many resources.

\section{The Aims Of ReSEARCH}

1) Reflection of the better-use of nanotechnology to achieve sustainability in architecture.

2) Clarify the significance of nanotechnology to architecture and the integration between them to show the nanoarchitecture and spotlight on the impact on architecture.

3) Trying to avoid nanotechnology's negative effects and stop the energy drain by finding alternative ways to conserve energy using nanomaterials.

\section{THE OBJECTIVS OF RESEARCH}

1) Know the positive benefits of nanomaterials in architecture and it's applied to clarify the potential risks and avoid them.

2) Identifying nanomaterials from their types, properties and use them in architecture.

3) Perfectly rethinking the connection between structure and skin in light of nanomaterials technology.

4) Applying the simulation model and analyze the outcome.

\section{METHODOLOGY}

The research methodology is based on simulation strategy that tries to modify some aspects of the physical environment in one of the various modes, from digital simulation software to a real scale status imitation.

\section{1) Applications}

The case study includes evaluation of energy performance and cooling loads for the "Specific Programs Building, Mansoura University" and comparison between the building in base case with normal materials and with nanomaterials case through a computer simulation program "DesignBuilder" to measure the impact of nanotechnology on the amount of energy consumed in the process of cooling and the average temperature of the thermal energy gained in the internal environment to achieve the main objective of the research.

2) Charts

- Specify the location of the case study and climate data.

- Prepare the drawing plans for the building.

-Analysis of the current state of the building using the DesignBuilder.

- Specify alternative solutions using Nanomaterials by the Design-Builder.

- Make a Comparison between the results for the current state case and the building after using Nanomaterials.

\section{A. Case Study Information}

The "Specific Programs Building" attached to the "Faculty of Engineering, Mansoura University" was chosen to be the case study. Fig. 13 shows the building and its location on Satellite Map.

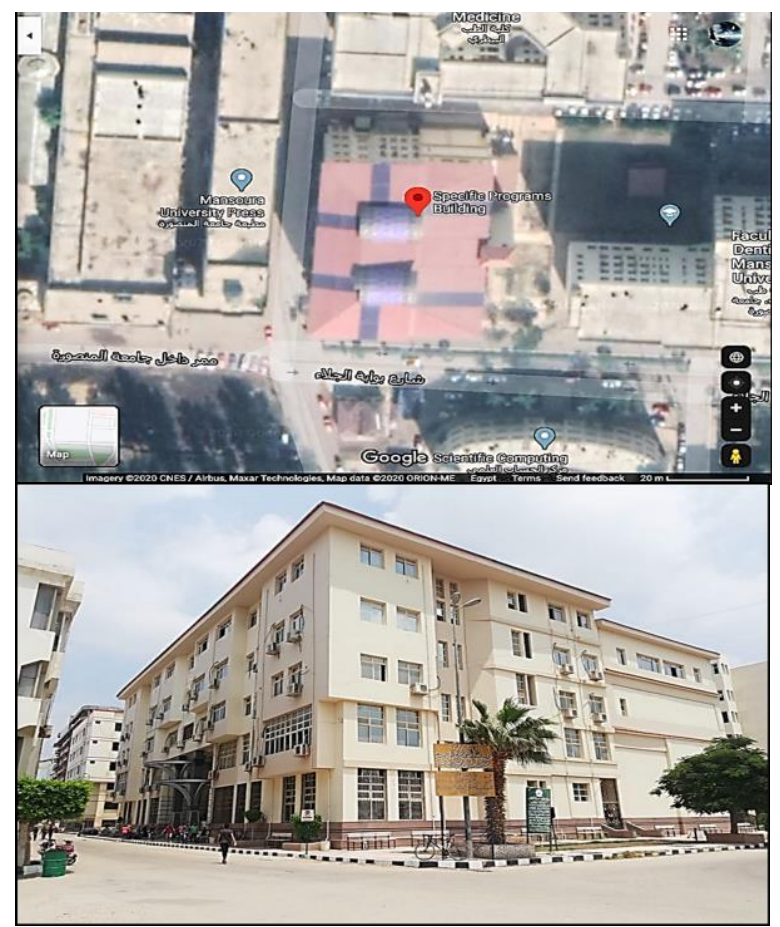

Fig. 13. Specific Programs Building. Mansoura Universitv and Satellite Map.

\section{B. The Climatic Data Used in Simulation}

The case study simulation is applied at Mansoura city "related to Cairo and Delta region". The climate of Mansoura city is similar to Cairo's climate. 


\section{1) Temperature}

The temperature ranges between $42^{\circ} \mathrm{C}$ in June as the highest temperature recorded in summer and $7^{\circ} \mathrm{C}$ in January as the lowest temperature recorded in winter as shown in Fig. 14 that was extracted from the "Climate Consultant" software.

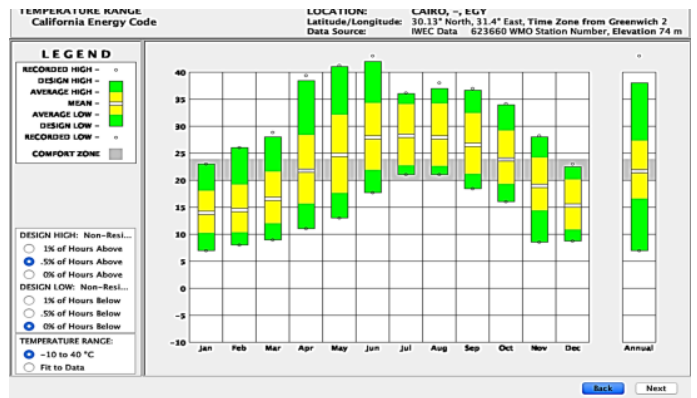

Fig. 14. Temperature range for Delta region generated by Climate Consultant.

2) Psychrometric Chart

The psychrometric chart of the Delta Region determines the characteristics of the climate which achieves the thermal comfort of the user from temperature as shown in Fig. 15 from the "Climate Consultant" software.

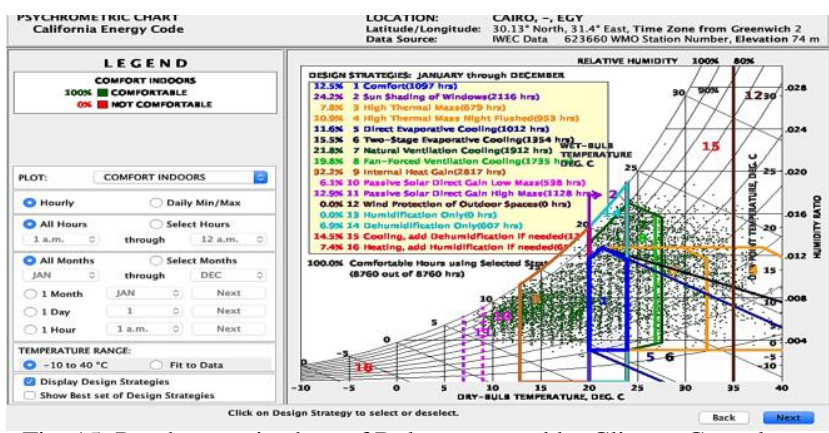

Fig. 15. Psychrometric chart of Delta generated by Climate Consultant.

\section{Modeling and Design the Case Study}

The building was simulated using "Design Builder" whereas; it is a state of the art software tool for checking building energy and comfort performance.

\section{Modeling and Design the Case Study}

1) Current Materials

\section{a) Walls Materials}

Walls consist of Brick-Burned with $20 \mathrm{~cm}$ thickness and two layers of Mortar-Cement with $2.5 \mathrm{~cm}$ thickness. Table 4 shows the physical characteristics for the wall.

TABLE 4

PHYSICAL CHARACTERISTICS OF THE WALL LAYERS.

\begin{tabular}{|c|c|c|c|c|c|}
\hline Component & \begin{tabular}{|c} 
Thickness \\
(cm)
\end{tabular} & $\begin{array}{c}\text { Conductivity } \\
\text { (W/m.K) }\end{array}$ & $\begin{array}{c}\text { Specific Heat } \\
(\mathrm{J} / \mathbf{k g} . \mathbf{K})\end{array}$ & \begin{tabular}{|l} 
Density \\
$(\mathbf{k g} / \mathbf{m} 3)$
\end{tabular} & \begin{tabular}{|l} 
Resistance \\
$\left(\mathrm{m}^{2} \cdot \mathrm{K} / \mathrm{W}\right)$
\end{tabular} \\
\hline $\begin{array}{l}\text { Mortar- } \\
\text { cement }\end{array}$ & 2.5 & 0.72 & 840 & 1860 & 0.022 \\
\hline Brick-burned & 20 & 0.85 & 840 & 1500 & 0.41 \\
\hline $\begin{array}{l}\text { Mortar- } \\
\text { cement }\end{array}$ & 2.5 & 0.72 & 840 & 1860 & 0.022 \\
\hline$R$-value & \multicolumn{5}{|c|}{$0.475\left(\mathrm{~m}^{2} . \mathrm{K} / \mathrm{W}\right)$} \\
\hline$U$-value & & & $106(\mathrm{~W} / \mathrm{m} 2 . \mathrm{K})$ & & \\
\hline
\end{tabular}

\section{b) Windows}

The glass used in the case study envelope is singleglazed with thickness $6 \mathrm{~mm}$. Table 5 shows the optical and physical properties of the glass used in the case study.
Table 6 shows the relationship between solid and void in the building envelope.

TABLE 5

OPTICAL AND PHYSICAL PROPERTIES OF THE USED GLASS.

\begin{tabular}{c||c||c||c} 
Type of glass & SHGC & VT & U-value (W/m2.K) \\
\hline Single glass $6 \mathrm{~mm}$ & 0.819 & 0.881 & 5.778
\end{tabular}

TABLE 6

WINDOWS-WALL RATIO IN FACADES.

\begin{tabular}{c||c||c||c||c} 
Orientation & $\begin{array}{c}\text { Facade Area } \\
(\mathbf{m} 2)\end{array}$ & $\begin{array}{c}\text { Wall Area } \\
(\mathbf{m} 2)\end{array}$ & $\begin{array}{c}\text { Window Area } \\
(\mathbf{m} 2)\end{array}$ & $\begin{array}{c}\text { Window-Wall } \\
\text { Ratio } \\
(\mathbf{\%})\end{array}$ \\
\hline North & 820 & 719.45 & 100.55 & $12.26 \%$ \\
\hline East & 1090 & 1081.36 & 8.64 & $0.79 \%$ \\
\hline South & 820 & 719.45 & 100.55 & $12.26 \%$ \\
\hline West & 1149.82 & 779.17 & 370.65 & $32.23 \%$ \\
\hline Total & $\mathbf{3 8 7 9 . 8 2}$ & $\mathbf{1 4 9 8 . 6 2}$ & $\mathbf{5 8 0 . 3 9}$ & $\mathbf{1 4 . 9 6 \%}$
\end{tabular}

c) Ceiling Materials

Table 7 shows the physical characteristics for the ceiling.

TABLE 7

PHYSICAL CHARACTERISTICS FOR THE CEILING LAYERS.

\begin{tabular}{|c|c|c|c|c|c|}
\hline Component & $\begin{array}{c}\text { Thickness } \\
(\mathbf{c m})\end{array}$ & $\begin{array}{c}\text { Conductivity } \\
(\mathbf{W} / \mathbf{m} \cdot \mathbf{K})\end{array}$ & \begin{tabular}{|c} 
Specific Heat \\
$(\mathbf{J} / \mathbf{k g} . \mathbf{K})$
\end{tabular} & \begin{tabular}{|l|} 
Density \\
$(\mathbf{k g} / \mathbf{m} 3)$
\end{tabular} & \begin{tabular}{|l} 
Resistance \\
$\left(\mathbf{m}^{2} \cdot \mathbf{K} / \mathbf{W}\right)$
\end{tabular} \\
\hline $\begin{array}{c}\text { Mortar- } \\
\text { cement }\end{array}$ & 5 & 0.72 & 840 & 1860 & 0.022 \\
\hline $\begin{array}{c}\text { Concrete, } \\
\text { Reinforced } \\
\text { (with } 2 \% \\
\text { steel) }\end{array}$ & 20 & 2.5 & 1000 & 2400 & 0.008 \\
\hline $\begin{array}{c}\text { Mortar- } \\
\text { cement }\end{array}$ & 5 & 0.72 & 840 & 1860 & 0.022 \\
\hline $\begin{array}{c}\text { Ceiling } \\
\text { Tiles }\end{array}$ & 5 & 0.056 & 1000 & 360 & 0.05 \\
\hline$R$-value & \multicolumn{5}{|c|}{$1.252\left(\mathrm{~m}^{2} . \mathrm{K} / \mathrm{W}\right)$} \\
\hline$U$-value & \multicolumn{5}{|c|}{$0.799(\mathrm{~W} / \mathrm{m} 2 . \mathrm{K})$} \\
\hline
\end{tabular}
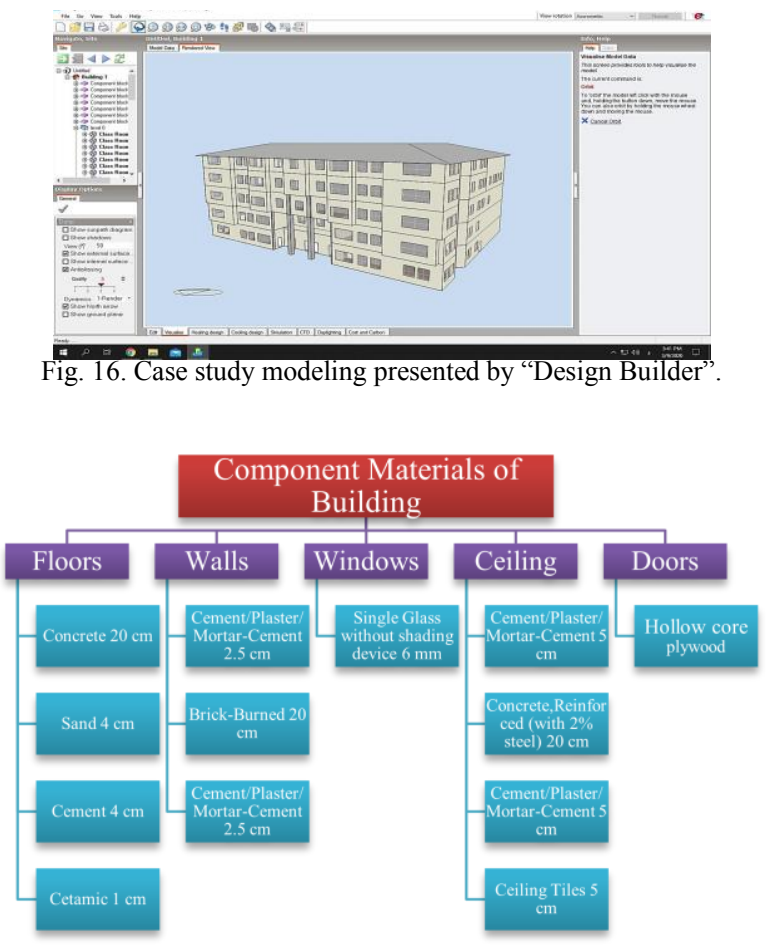

Fig. 17. Case study Current Materials. 

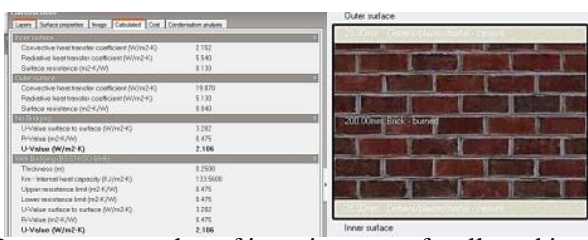

Fig. 18. Program screenshot of inserting type of walls and its properties.

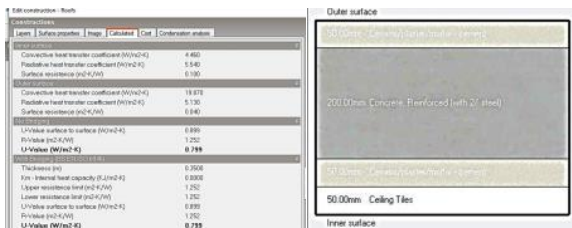

Fig. 19. Program screenshot of inserting type of ceiling and its properties.

2) Activity Operation

a) Set point temperatures (Cooling- Heating)

Setting of set point temperature for the cooling and heating shown in Fig. 20.

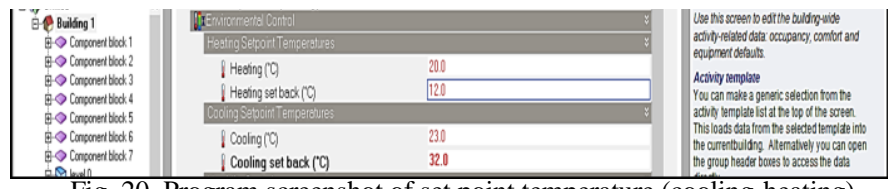

Fig. 20. Program screenshot of set point temperature (cooling-heating).

b) Schedule Operation

Building schedule operation shown in Fig. 21.

\begin{tabular}{|c|c|c|c|c|c|c|c|}
\hline \multicolumn{8}{|c|}{ Profiles } \\
\hline Mo.. & Monday & Tuesday & Wednesday & Thursday & Friday & Soturday & Sunday \\
\hline Jan & $9.00 \cdot 16: 00$ & $9: 00 \cdot 16: 00$ & $9.00 \cdot 16: 00$ & $9.00 \cdot 16: 00$ & Off & Off & $9.00 \cdot 16: 00$ \\
\hline Feb & $9.00-16: 00$ & $9: 00 \cdot 16: 00$ & $9: 00 \cdot 16: 00$ & $9.00 \cdot 16: 00$ & Off & Off & $9.00 \cdot 16: 00$ \\
\hline Mar & $9.00 \cdot 16: 00$ & $9: 00 \cdot 16: 00$ & $9: 00 \cdot 16: 00$ & $9.00 \cdot 16: 00$ & Off & Off & $9: 00 \cdot 16: 00$ \\
\hline Apt & $9.00 \cdot 16: 00$ & $9: 00 \cdot 16: 00$ & $9: 00 \cdot 16: 00$ & $9.00 \cdot 16: 00$ & Off & Off & $9: 00 \cdot 16: 00$ \\
\hline Мау & $9.00 \cdot 16: 00$ & $9: 00 \cdot 16: 00$ & $9: 00 \cdot 16: 00$ & $9.00 \cdot 16: 00$ & Off & Off & $9.00 \cdot 16: 00$ \\
\hline Jun & $9.00 \cdot 16: 00$ & $9: 00 \cdot 16: 00$ & $9: 00 \cdot 16: 00$ & $9.00 \cdot 16: 00$ & Off & Off & $9.00 \cdot 16: 00$ \\
\hline JuI & $9: 00 \cdot 16: 00$ & $9: 00 \cdot 16: 00$ & $9.00 \cdot 16: 00$ & $9: 00 \cdot 16: 00$ & Off & off & $9: 00 \cdot 16: 00$ \\
\hline Aug & $9.00-16: 00$ & $9: 00 \cdot 16: 00$ & $9: 00 \cdot 16: 00$ & $9.00 \cdot 16: 00$ & Off & Off & $9.00 \cdot 16: 00$ \\
\hline Sep & $9.00 \cdot 16: 00$ & $9: 00 \cdot 16: 00$ & $9: 00 \cdot 16: 00$ & $9.00 \cdot 16: 00$ & Off & Off & $9.00 \cdot 16: 00$ \\
\hline Oct & $9.00 \cdot 16: 00$ & $9: 00 \cdot 16: 00$ & $9: 00 \cdot 16: 00$ & $9.00 \cdot 16: 00$ & Off & Off & $9: 00 \cdot 16: 00$ \\
\hline Nov & $9: 00 \cdot 16: 00$ & $9: 00 \cdot 16: 00$ & $9.00 \cdot 16: 00$ & $9.00 \cdot 16: 00$ & Off & Off & $9.00 \cdot 16: 00$ \\
\hline Dec & $9.00 \cdot 16: 00$ & $9: 00 \cdot 16: 00$ & $9: 00 \cdot 16: 00$ & $9.00 \cdot 16: 00$ & Off & off & $9.00 \cdot 16: 00$ \\
\hline
\end{tabular}

Fig. 21. Program screenshot of Building schedule operation.

3) HVAC (Heating, Ventilation, and Air Conditioning)

Air conditioning system used in the building (split no fresh air).

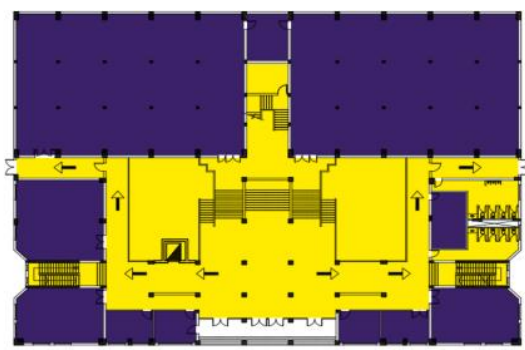

Ground Floor Plan

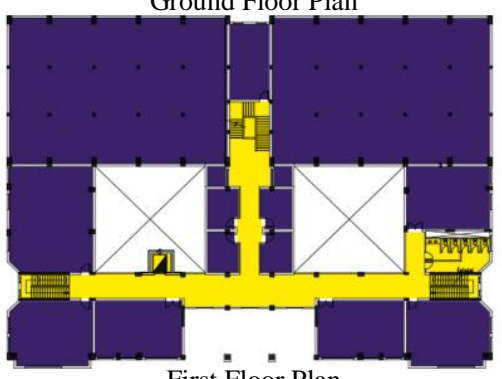

First Floor Plan

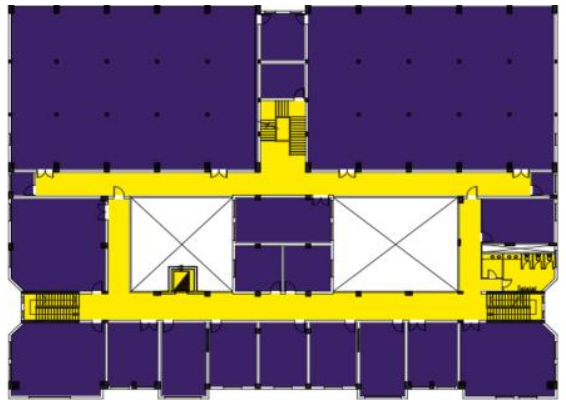

Second Floor Plan

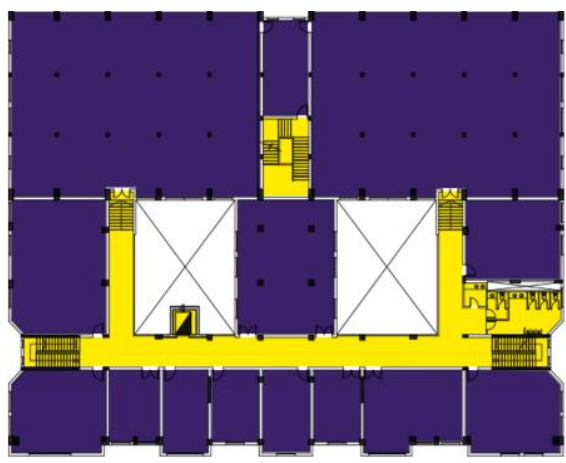

Third Floor Plan

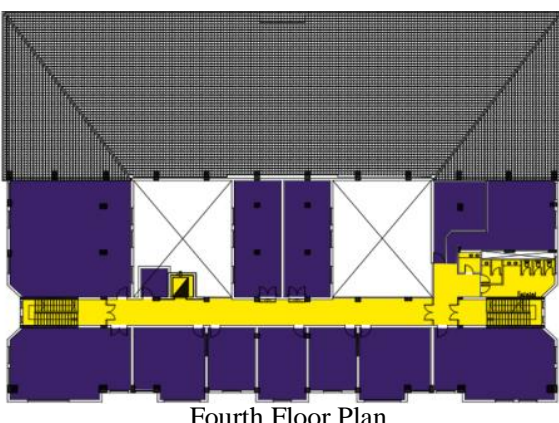

Fourth Floor Plan

Conditioner

Non-Conditionen:

Fig. 22. Conditioner and non-conditioner spaces.

\section{4) Output Data}

a) Cooling Power Consumption Rates for Interior Spaces

\begin{tabular}{|c|c|c|c|}
\hline Anal & Sumr & & \\
\hline Zo & & Block : & Total Cooling Load (kW) G \\
\hline & als & - & 1041.77 \\
\hline$<$ & & & \\
\hline Edit & Visualise & Heating & Cooling design \\
\hline
\end{tabular}

Fig. 23. Program screenshot of cooling load in "Base Case" on 15 July.

Total Cooling Load Over the Day $=1041.75 \mathrm{~kW}$

Total Cooling Load Over the Year $=535258.6818 \mathrm{kWh}$

Total Cooling (Electricity) Over the Year $=297365.9562 \mathrm{kWh}$ 


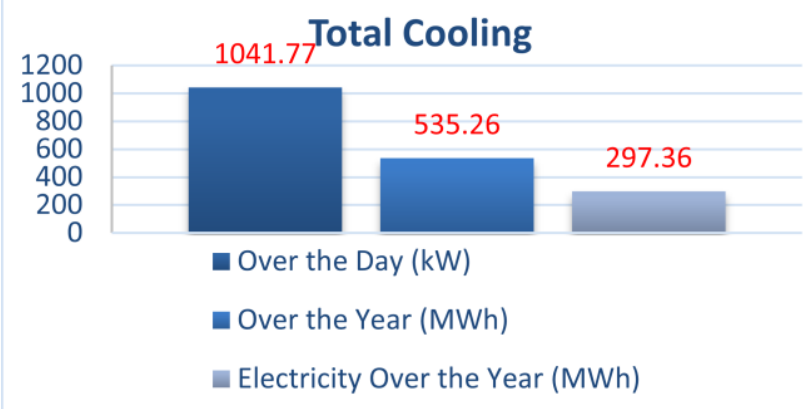

Chart 1. Total cooling loads in "Base Case".

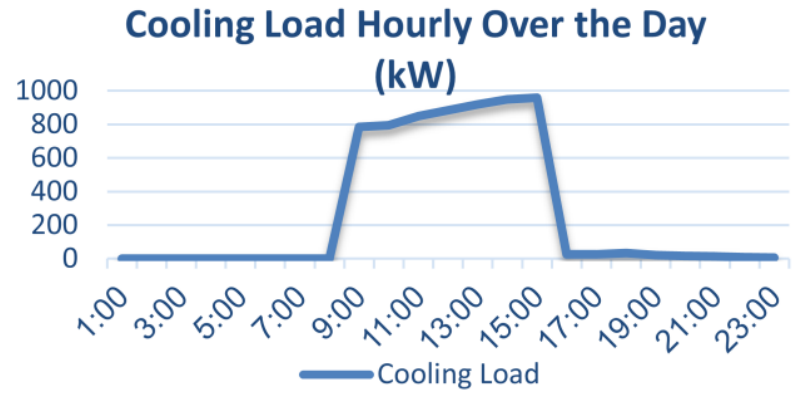

Chart 2. Cooling load hourly over the day in "Base Case".

b) Heat Gains Over the Day from Outside

\begin{tabular}{|c|c|c|c|c|}
\hline \multicolumn{2}{|c|}{ Glazing Gains (kW) } & Wall Gains (kV & W) Roof and Celing Gains ( $k W$ ] & Solar Gains (kW) [ \\
\hline \multicolumn{2}{|c|}{15.12} & 40.28 & -19.74 & $143.05 \quad 1$ \\
\hline Simulation & CFD & Daylighting & Cost and Carbon & \\
\hline
\end{tabular}

Fig. 24. Program screenshot of heat gains in" Base Case" on 15 July.

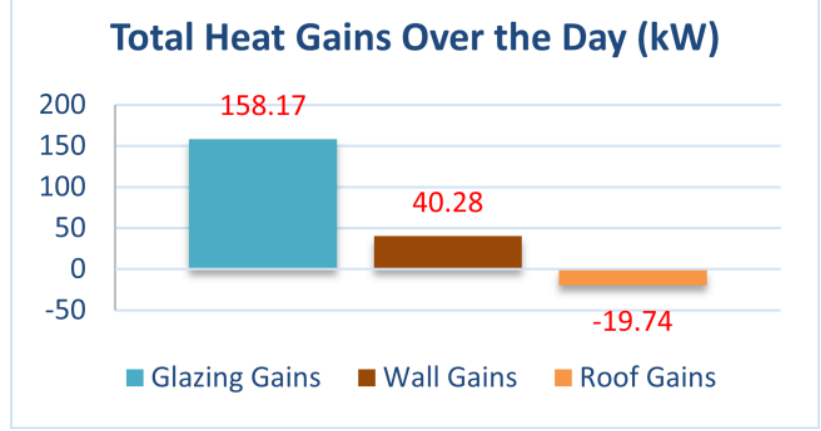

Chart 3. Total heat gains over the day in "Base Case".

c) Heat Gains Hourly Rate Over the Day from Outside

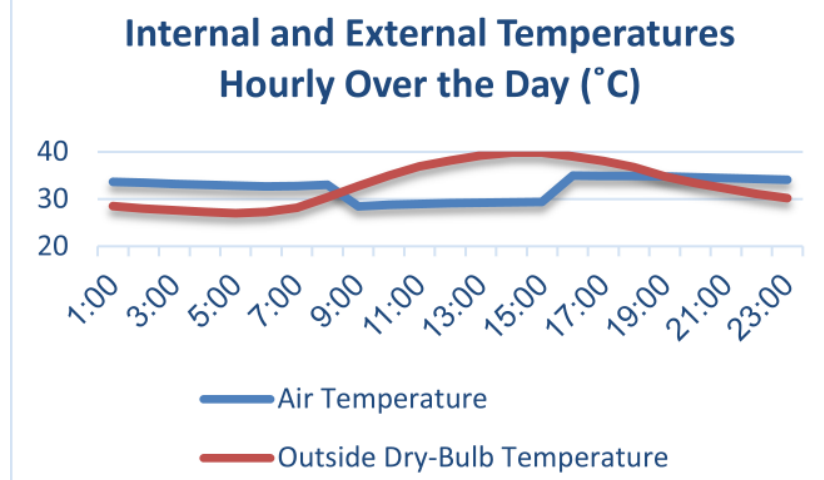

Chart 4. Int. and ext. temperature hourly over the day in "Base Case".

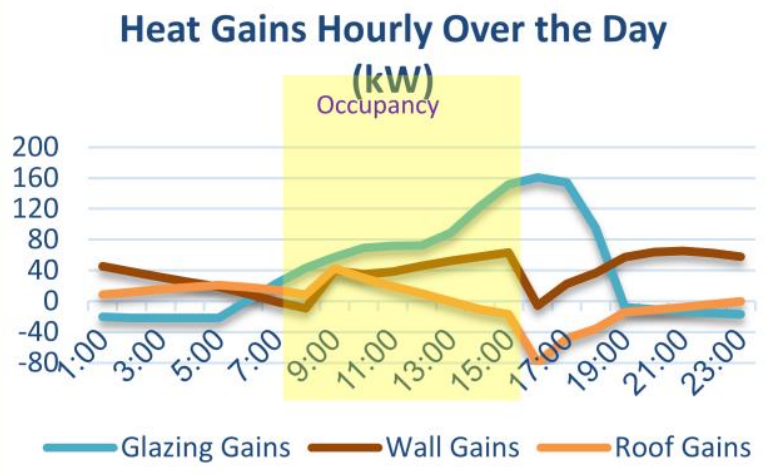

Chart 5. Heat gains hourly over the day in "Base Case".

d) Comfort and Setpoint Not Met Summary

Comfort and Setpoint Not Met Summary

\begin{tabular}{|r|r|}
\hline & Facility [Hours] \\
\hline Time Setpoint Not Met During Occupied Heating & 0.00 \\
\hline Time Setpoint Not Met During Occupied Cooling & 48.00 \\
\hline Time Not Comfortable Based on Simple ASHRAE 55-2004 & 1561.00 \\
\hline
\end{tabular}

Fig. 25. Comfort and Setpoint Not Met Summary in "Base Case".

E. Nano Vacuum Insulation Panels (VIP) Case

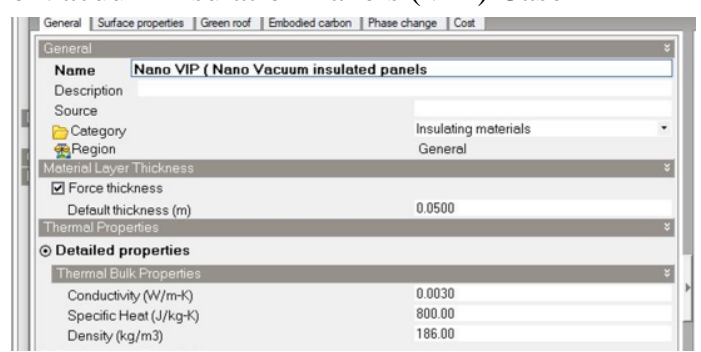

Fig. 26. Physical characteristics of the "Nano VIP" Material.

1) Current Materials

a) Walls Materials

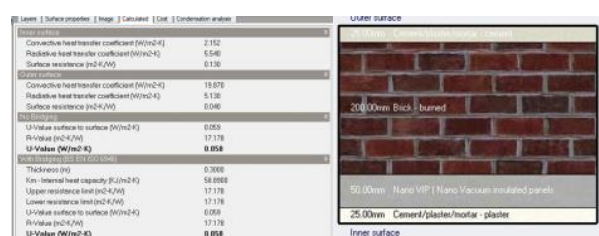

Fig. 27. Program screenshot of inserting type of walls and its properties. 
b) Ceiling Materials

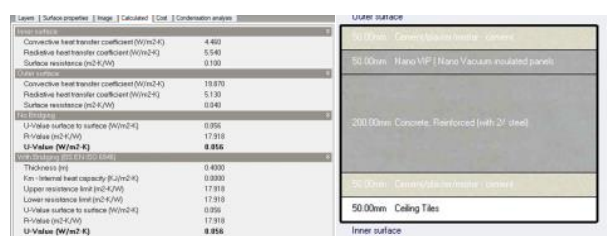

Fig. 28. Program screenshot of inserting type of ceiling and its properties.

2) Output Data

a) Cooling Power Consumption Rates for Interior Spaces

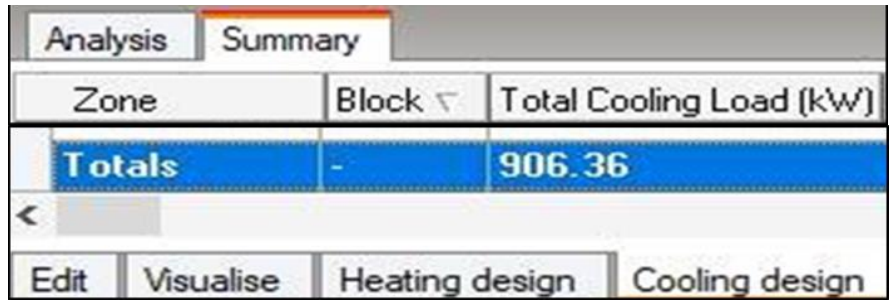

Fig. 29. Program screenshot of total cooling load in "VIP Case" on 15 July.

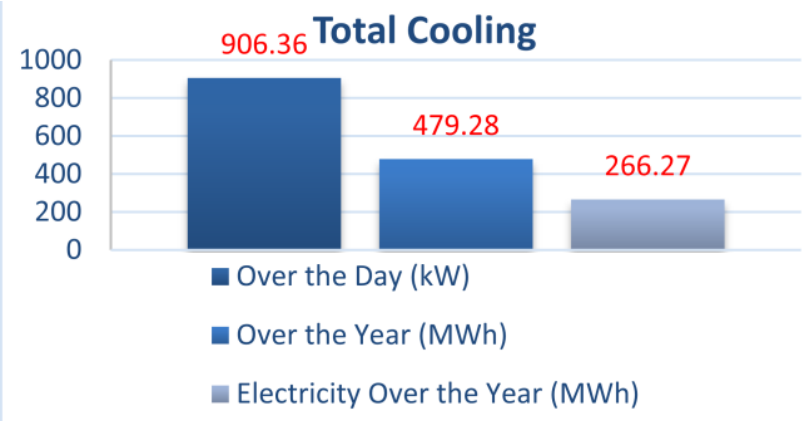

Chart 6. Total cooling loads in "VIP Case".

Total Cooling Load Over the Day $=906.36 \mathrm{~kW}$.

Total Cooling Load Over the Year $=479286.58 \mathrm{kWh}$.

Total Cooling (Electricity) Over the Year $=266270.4 \mathrm{kWh}$.

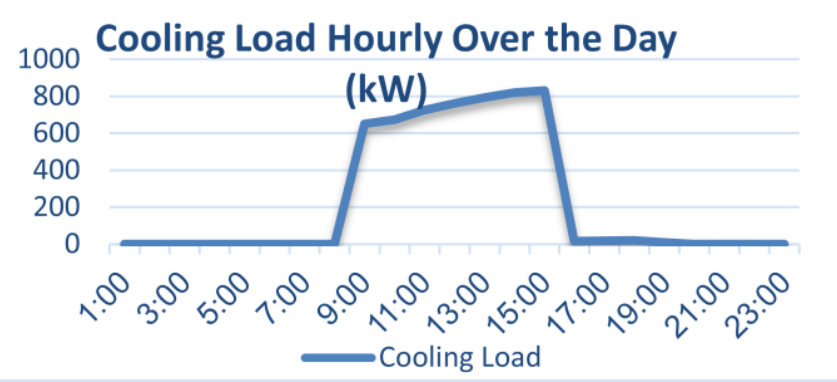

Chart 7. Cooling load hourly over the day in "VIP Case".

\section{b) Heat Gains Over the Day from Outside}

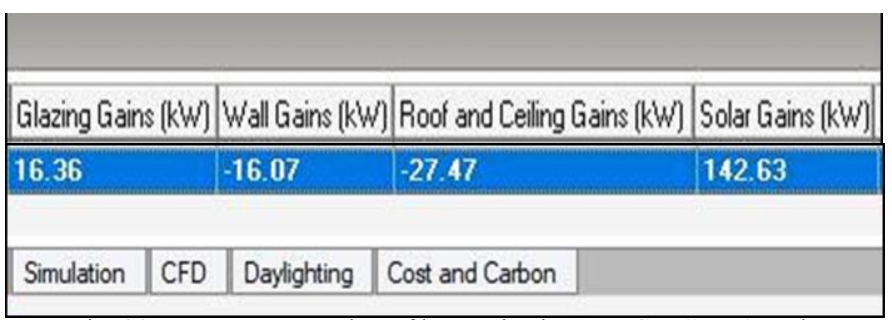

Fig. 30. Program screenshot of heat gains in "VIP Case" on 15 July.
Total Heat Gains Over the Day (kW)

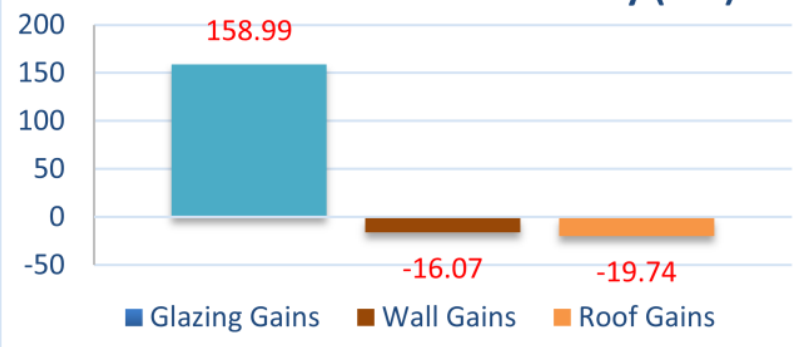

Chart 8. Total heat gains over the day in "VIP Case".

c)Heat Gains Hourly Rate Over the Day from Outside

\section{Internal and External Tempratures Hourly Over the Day $\left({ }^{\circ} \mathrm{C}\right)$}

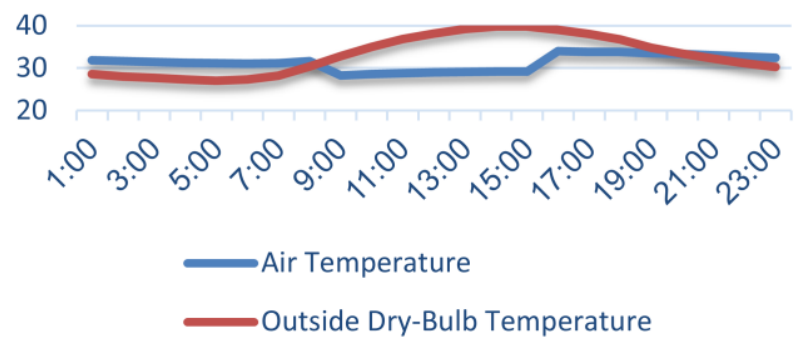

Chart 9. Int. and ext. temperature hourly over the day in "VIP Case".

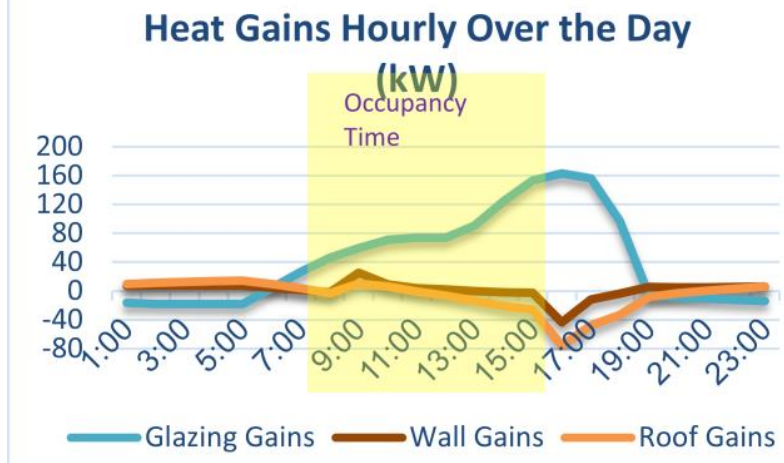

Chart 10. Heat gains hourlv over the dav in "VIP Case".

d) Comfort and Setpoint Not Met Summary

Comfort and Setpoint Not Met Summary

\begin{tabular}{|r|r|}
\hline & Facility [Hours] \\
\hline Time Setpoint Not Met During Occupied Heating & 0.00 \\
\hline Time Setpoint Not Met During Occupied Cooling & 107.50 \\
\hline Time Not Comfortable Based on Simple ASHRAE 55-2004 & 1524.00 \\
\hline
\end{tabular}

Fig. 31. Comfort and Setpoint Not Met Summary "VIP Case".

F. Aerogel Case

\begin{tabular}{|c|c|c|}
\hline \multicolumn{3}{|l|}{ Name AEROGEL 10MM } \\
\hline Source & BSEN 673/E+ & \\
\hline Category & Other & - \\
\hline Thickness (mm) & 10.000 & \\
\hline \multirow{2}{*}{\multicolumn{3}{|c|}{$\begin{array}{l}\text { Gas definition } \\
\text { Custom }\end{array}$}} \\
\hline & & \\
\hline Conductivity coefficient $\mathrm{A}(\mathrm{W} / \mathrm{m}-\mathrm{K})$ & 0.00287300 & \\
\hline Conductivity coefficient $\mathrm{B}(\mathrm{W} / \mathrm{m}-\mathrm{K} 2)$ & 0.00007760 & \\
\hline Conductivity coefficient $C(W / m-k 3)$ & 0.00000000 & \\
\hline Viscosity coefficient $A(\mathrm{~kg} / \mathrm{m}-\mathrm{s})$ & 0.0000037230 & \\
\hline $\begin{array}{l}\text { Viscosity coenticient } \mathrm{A}(\mathrm{kg} / \mathrm{m} / \mathrm{s}) \\
\text { Viscosity coefficient } \mathrm{B}(\mathrm{k} / \mathrm{m}-\mathrm{s}\end{array}$ & 0.0000000494 & \\
\hline Viscosity coefficient $\mathrm{C}(\mathrm{kg} / \mathrm{m}-\mathrm{s}-\mathrm{K}$ ) & 0.0000000000 & \\
\hline Specific heat coefficient A $(\mathrm{J} / \mathrm{kg}-\mathrm{K})$ & 1002.7400 & \\
\hline Specific heat coefficient $B(J / k g-K 2)$ & 0.0000000 & \\
\hline Specific heat coefficient $C(\mathrm{~J} / \mathrm{kg}-\mathrm{K} 3)$ & 0.0000000 & \\
\hline Molecular weight $(\mathrm{kg} / \mathrm{kmol})$. & 28.970 & \\
\hline Specificheat ratio & 1500 & \\
\hline
\end{tabular}

Fig. 32. Physical characteristics of the "Aerogel" Material. 
1) Current Materials

a) Windows

\begin{tabular}{|c|c|}
\hline \multicolumn{2}{|l|}{ 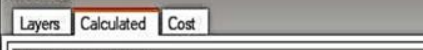 } \\
\hline & \\
\hline Total soler transmission (SHGC) & 0.454 \\
\hline Direct solar transmission & 0.338 \\
\hline Lightrtransmisssion & 0.624 \\
\hline Uvalue (ISO 10292/ EN 673) (W/m2-K) & \\
\hline U-Value (W/m2-K) & 0.965 \\
\hline
\end{tabular}

Fig. 33. Program screenshot of inserting type of glass and its properties.

2) Output Data

a) Cooling Power Consumption Rates for Interior Spaces

\begin{tabular}{|c|c|c|c|}
\hline \multicolumn{4}{|c|}{ Analysis } \\
\hline \multicolumn{2}{|c|}{ Zone } & Block 5 & Total Cooling Load (kW) \\
\hline \multicolumn{2}{|c|}{ Totals } & 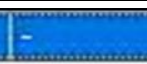 & 1002.68 \\
\hline \multicolumn{4}{|c|}{$<$} \\
\hline Edit & Visualise & Heating & Cooling design \\
\hline
\end{tabular}

Fig. 34. Program screenshot of total cooling load in"Aerogel Case"on 15 July.

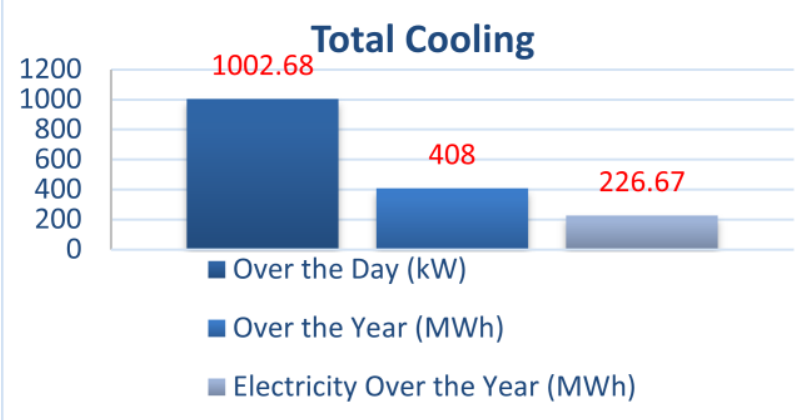

Chart 11. Total cooling loads in "Aerogel Case".

Total Cooling Load Over the Day $=1002.68 \mathrm{~kW}$.

Total Cooling Load Over the Year $=408004.61 \mathrm{kWh}$.

Total Cooling (Electricity) Over the Year $=226669.23 \mathrm{kWh}$.

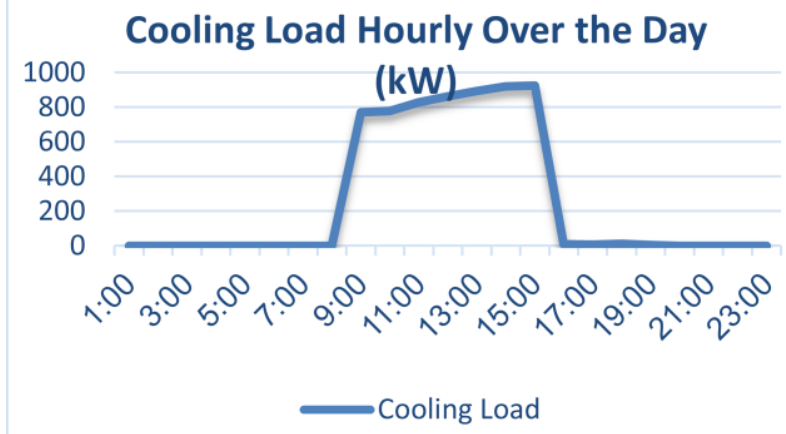

Chart 12. Cooling load hourly over the day in "Aerogel Case".

b) Heat Gains Over the Day from Outside

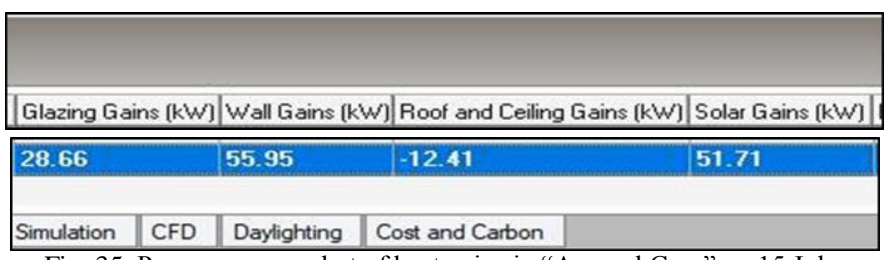

Fig. 35. Program screenshot of heat gains in "Aerogel Case" on 15 Julv.
Total Heat Gains Over the Day (kW)

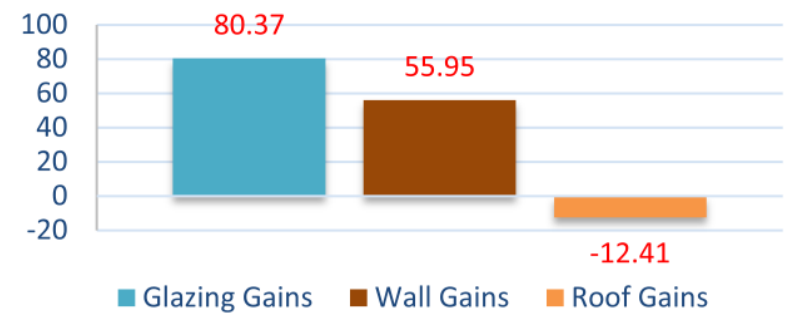

Chart 13. Total heat gains over the day in "Aerogel Case".

c) Heat Gains Hourly Rate Over the Day from Outside

\section{Internal and External Tempratures Hourly Over the Day $\left({ }^{\circ} \mathrm{C}\right)$}

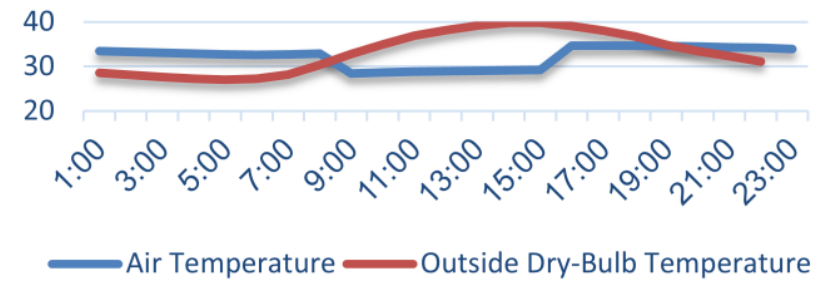

Chart 14. Int. and ext. temperature hourly over the day in "Aerogel Case".

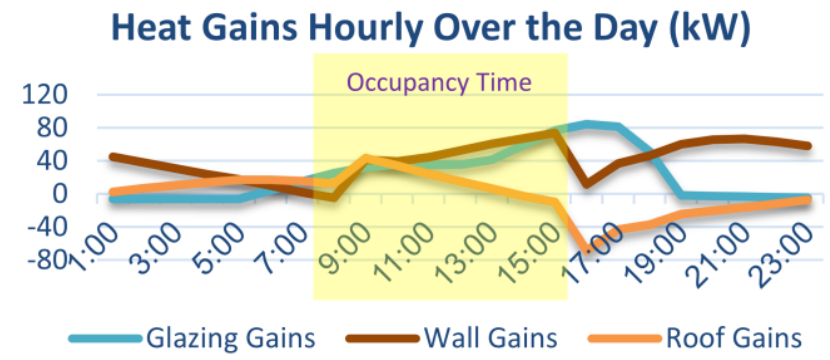

Chart 15. Heat gains hourly over the day in "Aerogel Case".

d) Comfort and Setpoint Not Met Summary

Comfort and Setpoint Not Met Summary

\begin{tabular}{|r|r|}
\hline & Facility [Hours] \\
\hline Time Setpoint Not Met During Occupied Heating & 0.00 \\
\hline Time Setpoint Not Met During Occupied Cooling & 39.00 \\
\hline Time Not Comfortable Based on Simple ASHRAE 55-2004 & 1483.00 \\
\hline
\end{tabular}

Fig. 36. Comfort and Setpoint Not Met Summary “Aerogel Case”.

G. VIP + Aerogel Case

1) Output Data

a) Cooling Power Consumption Rates for Interior Spaces

\begin{tabular}{|c|c|c|c|}
\hline \multicolumn{4}{|c|}{ Untitled, Building 1} \\
\hline Analysis & Summ & & \\
\hline \multicolumn{2}{|l|}{ Zone } & Block 5 & Total Cooling Load (kW) \\
\hline \multicolumn{2}{|l|}{ Totals } & - & 850.28 \\
\hline \multicolumn{4}{|l|}{$<$} \\
\hline Edit & Visualise & Heating design & Cooling design \\
\hline
\end{tabular}

Fig. 37. Program screenshot of total cooling load in"VIP+Aerogel"on 15 July. 


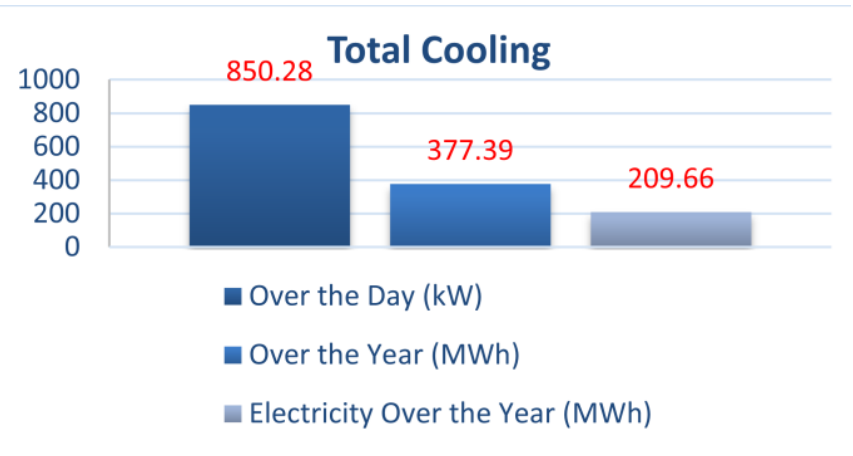

Chart 16. Total cooling loads in "VIP+Aerogel".

Total Cooling Load Over the Day $=850.28 \mathrm{~kW}$.

Total Cooling Load Over the Year $=377392.1375 \mathrm{kWh}$.

Total Cooling (Electricity) Over the Year $=209662.241 \mathrm{kWh}$.

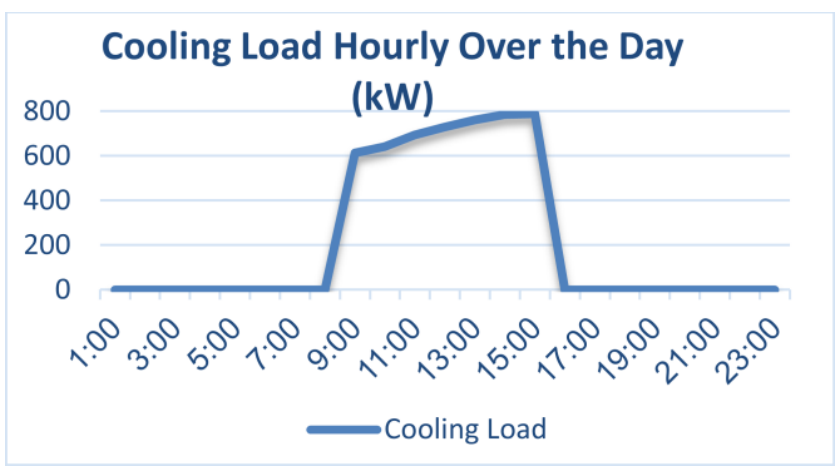

Chart 17. Cooling load hourly over the day in "VIP+Aerogel".

b) Heat Gains Over the Day from Outside

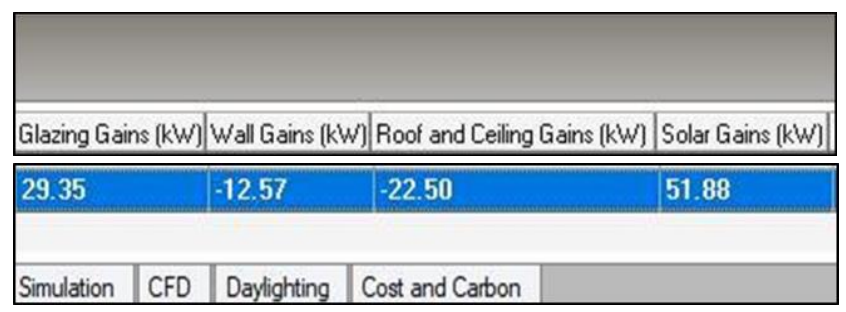

Fig. 38. Program screenshot of heat gains in "VIP+Aerogel" on 15 July.

Total Heat Gains Over the Day (kW)

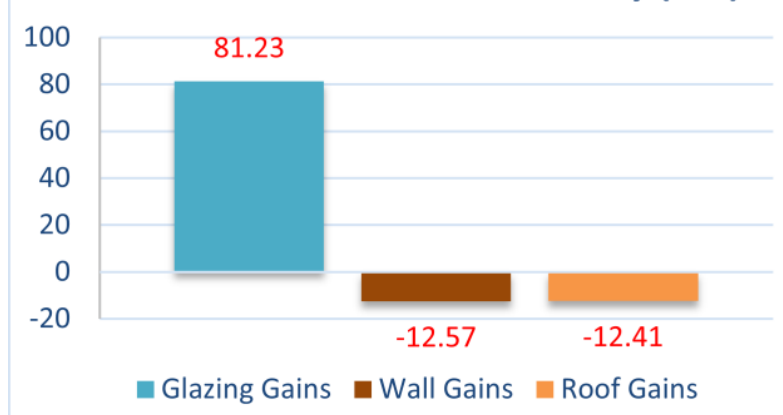

Chart 18. Total heat gains over the day in "VIP+Aerogel". c) Heat Gains Hourly Rate Over the Day from Outside

\section{Internal and External Tempratures Hourly Over the Day $\left({ }^{\circ} \mathrm{C}\right)$}

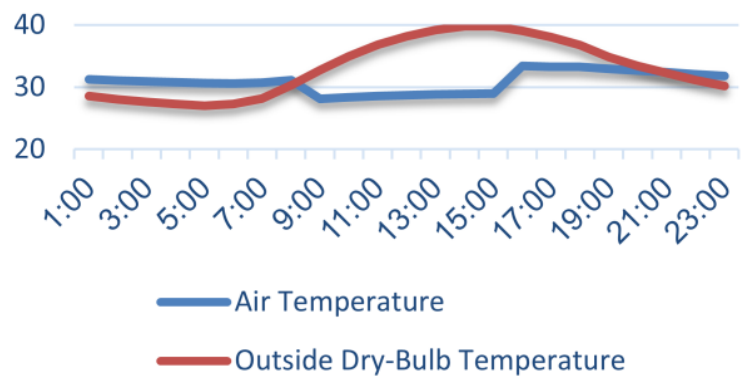

Chart 19. Int. and ext. temperature hourly over the day in "VIP+Aerogel".

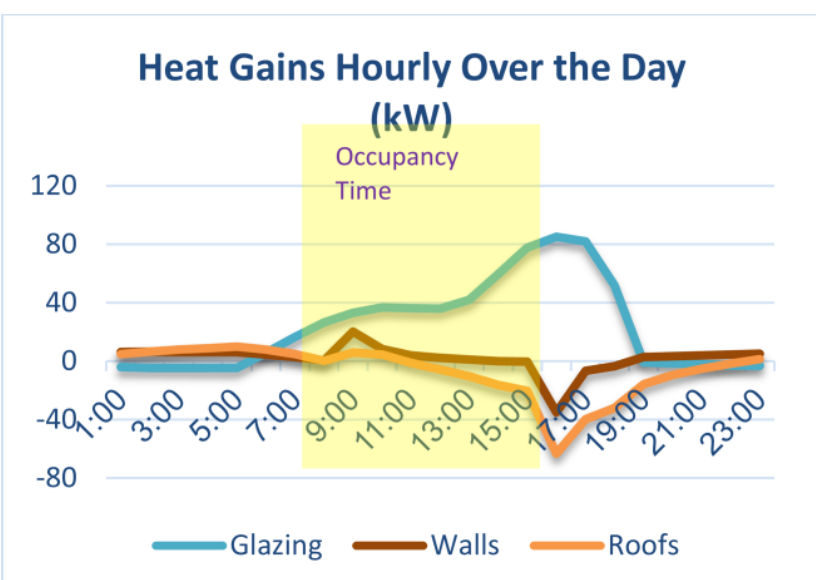

Chart 20. Heat gains hourly over the day in "VIP+Aerogel".

d) Comfort and Setpoint Not Met Summary

Comfort and Setpoint Not Met Summary

\begin{tabular}{|r|r|}
\hline & Facility [Hours] \\
\hline Time Setpoint Not Met During Occupied Heating & 0.00 \\
\hline Time Setpoint Not Met During Occupied Cooling & 127.00 \\
\hline Time Not Comfortable Based on Simple ASHRAE 55-2004 & 1417.00 \\
\hline
\end{tabular}

Fig. 39. Comfort and Setpoint Not Met Summary "VIP+Aerogel".

\section{RESULTS}

By Comparing "Base Case" with other cases, the following is concluded:

\section{Cooling Power Consumption Rates for Interior Spaces}

Charts 21, 22, 23 show the total cooling loads and electricity for all cases.

- Nano Vacuum Insulation Panels (VIP) Case:

Total cooling loads over the day decreased by $13 \%$.

Total cooling loads over the year decreased by $10.5 \%$.

Total cooling (Electricity) over the year decreased by $10.5 \%$.

- Aerogel Case:

Total cooling loads over the day decreased by $3.8 \%$.

Total cooling loads over the year decreased by $23.8 \%$.

Total cooling (Electricity) over the year decreased by $23.8 \%$. 
- VIP+Aerogel Case:

Total cooling loads over the day decreased by $18.4 \%$.

Total cooling loads over the year decreased by $29.5 \%$.

Total cooling (Electricity) over the year decreased by $29.5 \%$

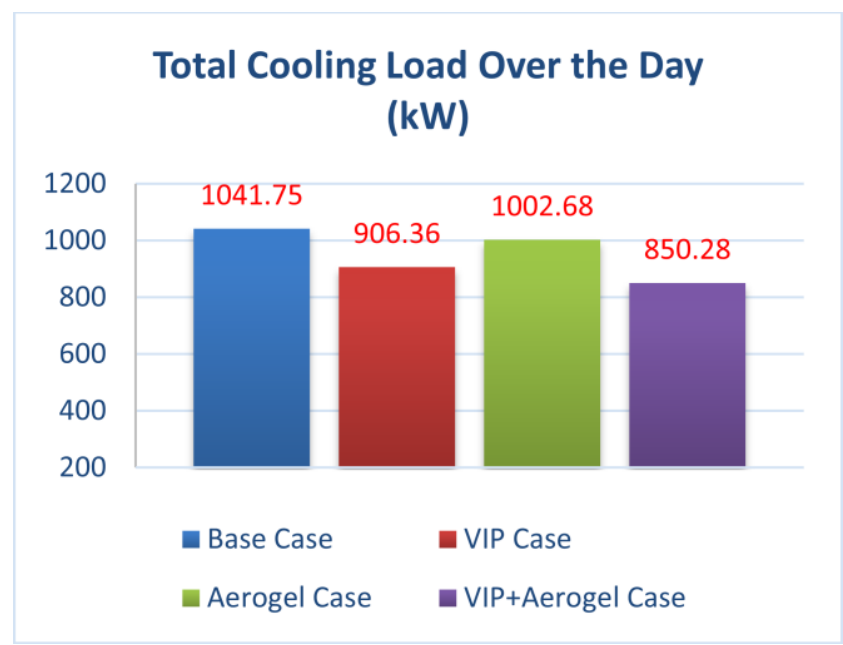

Chart 21. Total cooling load over the day.

\section{Total Cooling Load Over the Year (MWh)}

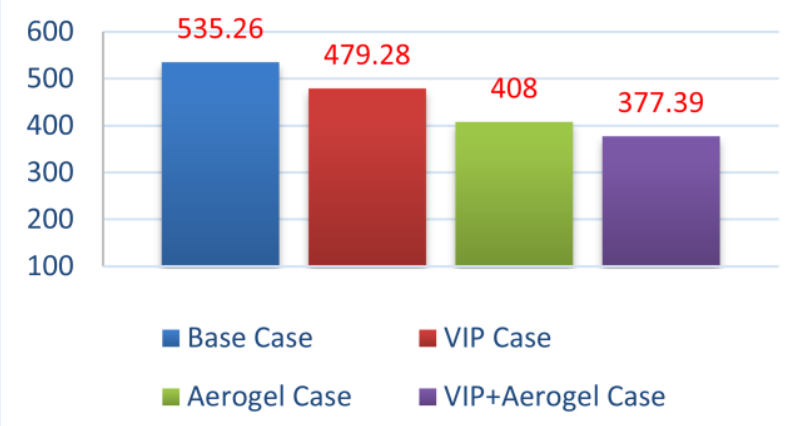

Chart 22. Total cooling load over the year.

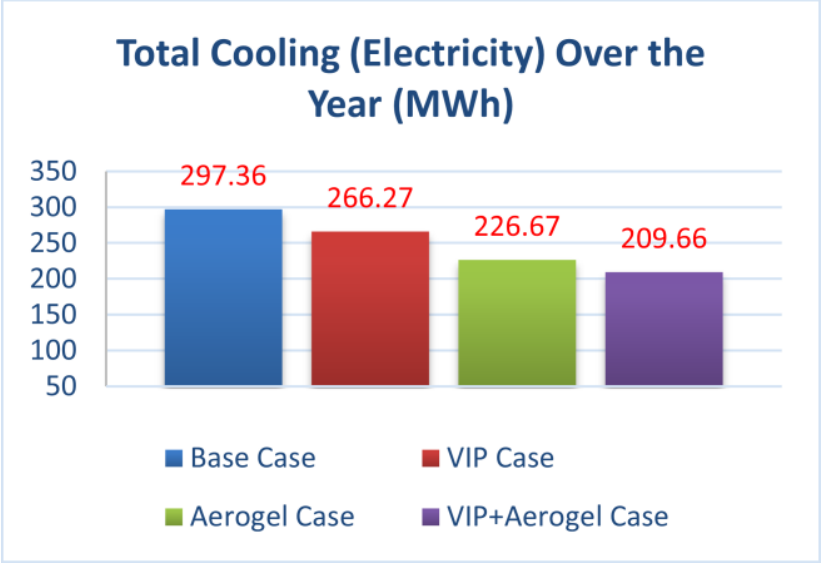

Chart 23. Total cooling (Electricity) over the year.

\section{Heat Gains Over the Day from Outside}

Chart 24 shows the total heat gains from the outer shell of the building over the day (glazing, walls and roofs).

- In "VIP Case", the heat gain decreased by $35.4 \%$ from "Base Case".

- In "Aerogel Case", the heat gain decreased by $30.7 \%$ from "Base Case".

- In "VIP+Aerogel Case", the heat gain decreased by $74.2 \%$ from "Base Case".

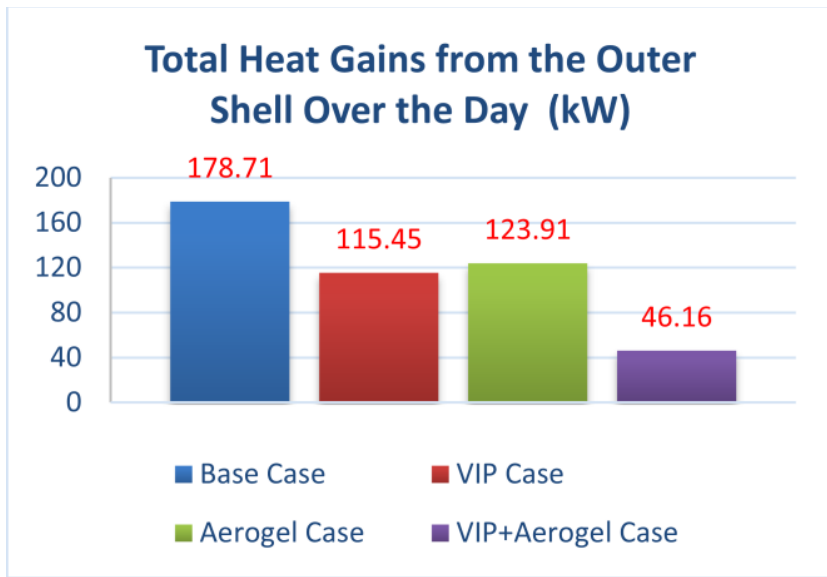

Chart 24. Total heat gains from the outer shell over the day.

\section{Comfort and Setpoint Not Met Summary}

- In "VIP Case", the time setpoint not met during occupied cooling decreased by $2.4 \%$ from "Base Case".

- In "Aerogel Case", the time setpoint not met during occupied cooling decreased by $5 \%$ from "Base Case".

- In "VIP+Aerogel Case", the time setpoint not met during occupied cooling decreased by $9.2 \%$ from "Base Case".

\section{Time Setpoint not Met During Occupied Cooling Over the Year (h)}

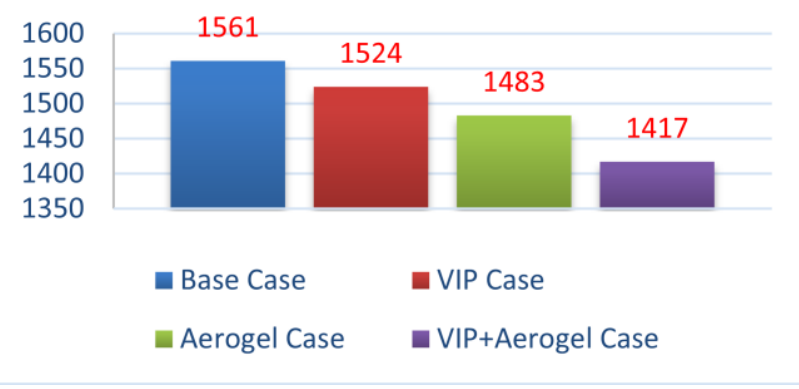

Chart 25. Time setpoint not met during occupied cooling over the year

From the previous results, it is observed that the "VIP+Aerogel case" is the most optimized as the cooling power consumption decreased by $29.5 \%$, the heat gain decreased by $74.2 \%$ and the time setpoint not met during occupied cooling decreased by $9.2 \%$ from the "Base Case". Table 8 . 
TABLE 8

COMPARISON BETWEEN DECLINE RATES IN THREE CASES.

\begin{tabular}{|c|c|c|c|c|c|}
\hline & \multicolumn{3}{|c|}{$\begin{array}{l}\text { Cooling Power Consumption Rates } \\
\text { for Interior Spaces }\end{array}$} & \multirow{2}{*}{$\begin{array}{l}\text { Heat Gains Over the } \\
\text { Day from Outside }\end{array}$} & \multirow{2}{*}{$\begin{array}{c}\text { Comfort and Setpoint Not Me } \\
\text { Summary }\end{array}$} \\
\hline & $\begin{array}{l}\text { Total cooling } \\
\text { loads over the } \\
\text { day }\end{array}$ & $\begin{array}{l}\text { Total cooling } \\
\text { loads over the } \\
\text { year }\end{array}$ & $\begin{array}{l}\text { Total cooling } \\
\text { (Electricity) over } \\
\text { the year }\end{array}$ & & \\
\hline VIP & $13 \%$ & $10.5 \%$ & $10.5 \%$ & $35.4 \%$ & $2.4 \%$ \\
\hline Aerogel & $3.8 \%$ & $23.8 \%$ & $23.8 \%$ & $30.7 \%$ & $5 \%$ \\
\hline VIP+Aerogel & $18.4 \%$ & $29.5 \%$ & $29.5 \%$ & $74.2 \%$ & $9.2 \%$ \\
\hline
\end{tabular}

\section{CONCLUSION AND Recommendations}

Nanotechnology has enormous potential to advance human life, and the use of nanomaterials in construction has helped increase the performance and high rating of buildings to achieve sustainability compatible with the environment and with advanced classifications in global building evaluation systems.

This research recommends the following:

- Use "Design Builder" or any similar software as a building simulation tool to ensure the best design while applying sustainability principles to increase user comfort inside the Space.

- Use Aerogel as a nanomaterial insulation system for windows and curtain walls to reduce heat gain from the outside and thus increase the efficiency of the cooling system.

- Use vacuum insulation panels (VIPs) in the building envelope to reduce the temperature rise in conjunction with high energy consumption in the building cooling process.

- Using more than one insulation system at the same time to completely isolate the building envelope, which leads to rationalizing energy consumption and reducing its cost, thus reducing the energy crisis in general.

\section{REFERENCES}

[1] Nanotechnology Now. (2015, April 20). Nanotechnology Introduction. [Online]. Available:

http://www.nanotech-now.com/introduction.htm

[2] "What is Nanotechnology? A Guide,". Nano Magazine, (June, 2013). [Online]. Available: http://www.swednanotech.com/wpcontent/uploads/2013/06/3.004_Nanotechnology-a-guide.pdf

[3] A. Nouailhat. What are Nanos?:An Introduction to Nanoscience and Nanotechnology, 1st ed., New Jersey \& London, UK: Wiley-ISTE Ltd.

[4] O. M. Omar. (2015, April). Nanoarchitecture Future Housing. Presented at Jordan Housing Developers Association Conf., At Amman, Jordan. [Online]. Available: https://www.academia.edu/11862605/Nanoarchitecture_Future_Hosing

[5] Wikipedia. (2021, January 5). Nanomaterials. [Online]. Available: https://en.wikipedia.org/wiki/Nanomaterials

[6] L. filipponi, D. Stherland. (2010, September). Nanotechnology: A Brief Introduction. INANO, University of Aarhus, Denmark. [Online]. Available: https://nanoyou.eu/attachments/188 Module-1-chapter-1.pdf

[7] S. Mann. (2006, October), Retrieved (2012, January). Nanotechnology and Construction. European Nanotechnology Gateway, Institute of Nanotechnology. [Online]. Available: https://www.nanowerk.com/nanotechnology/reports/reportpdf/report62.pdf

[8] M. Zhang, Sh. Feng, L. Wang, Y. Zheng. (2016, March). Lotus effect in wetting and self-cleaning. Biotribology. Volume 5, PP 31-43. [Online]. Available: https://doi.org/10.1016/j.biotri.2015.08.002.

[9] B. Bhushan, M. Nosonovsky. (2012). Encyclopedia of Nanotechnology: Lotus Effect. [Online]. Available: https://doi.org/10.1007/978-90-481$\underline{9751-4 \_158}$
[10] R. Bianchini. (2019, November). Museum of the Ara Pacis. Inexhibit. [Online]. Available: https://www.inexhibit.com/mymuseum/ara-pacismuseum-rome-richard-meier/

[11] N. B. McGuinness, H. John, M. K. Kavitha, S. Banerjee, D. D. Dionysiou and S. C. Pillai. (2016, April 4). Photocatalysis: Applications. [Online]. Available: $\underline{\text { https://doi.org/10.1039/9781782627104-00204 }}$

[12] M. D. Safiuddin, K. Hossain, and C. M. Collins. (2018, June). Potential Applications of Self-Cleansing Nano Lotus Leaf Biomimicked Coating in Different Construction Sectors. CSCE 2018 Annual ConferenceAt: Fredericton, New Brusmwick. [Online]. Available: https://www.researchgate.net/publication/324827998_Potential_Applicatio ns of Self-

Cleansing Nano Lotus Leaf Biomimicked Coating in Different Constr uction Sectors

[13] Wikipedia. (2020, February 18). Muhammad Ali Center. [Online]. Available: https://en.wikipedia.org/wiki/Muhammad Ali_Center

[14] NanoWerk. (2011, January 11). Nanotechnology solutions for selfcleaning, dirt and water-repellent coatings. [Online]. Available: https://www.nanowerk.com/spotlight/spotid=19644.php

[15] M. Casini. (2016). Smart Buildings. ( $1^{\text {st }}$ ed.) [Online]. Available: https://doi.org/10.1016/B978-0-08-100635-1.00004-6

[16] Wikipedia. (2020, June 6). Vacuum insulated panel. [Online]. Available: https://en.wikipedia.org/wiki/Vacuum insulated panel

[17] D. Levy, M. Zayat. (2015, August 21). The Sol- Gel Handbook. ( $1^{\text {st }}$ ed.) [Online]. Available: https://doi.org/10.1002/9783527670819.ch17

[18] L. Meliță, C. Croitoru. (2019, August 13). Aerogel, a high performance material for thermal insulation - A brief overview of the building applications. E3S Web of Conferences. 111(43) [Online]. Available: https://doi.org/10.1051/e3sconf/201911106069

[19] J.M.P.Q. Delgado, J. C. Martinho, A. Vaz Sá, A. S. Guimarães, and V. Abrantes. (2019). Thermal Energy Storage with Phase Change Materials: A Literature Review of Applications for Buildings Materials. ( $1^{\text {st }}$ ed.) [Online]. Available: https://doi.org/10.1007/978-3-319-97499-6

[20] C. M. Hussain. (2018). Handbook of Nanomaterials for Industrial Applications: A volume in Micro and Nano Technologies. (1st ed.) [Online]. Available: https://doi.org/10.1016/C2016-0-04427-3

[21] J. Moma, J. Baloyi. (2019, January). Photocatalysts Applications and Attributes: Modified Titanium Dioxide for Photocatalytic Applications. (1st ed.) [Online]. Available: https://cdn.intechopen.com/pdfs/62303.pdf

\section{Title Arabic:}

$$
\text { تقنيات النانو المنآلفة بيئياً في العمارة من أجل تطبيقات الجيل النتالي من }
$$

\section{Arabic Abstract:}

يسلط البحث الضوء على التطور الملحوظ في الفترة الأخيرة من تقام في مجال

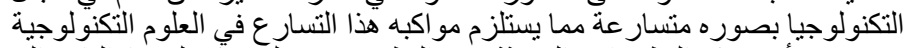

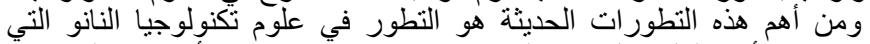

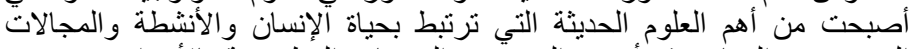

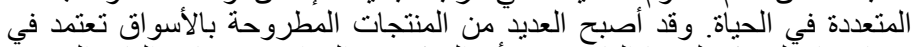

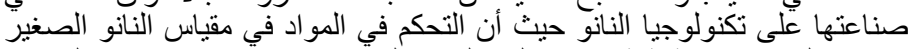

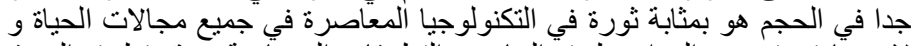

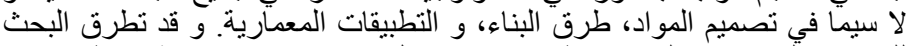

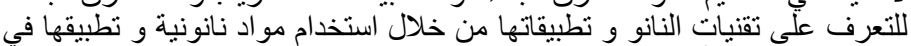

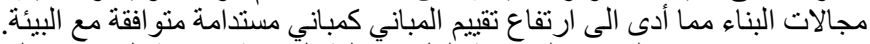

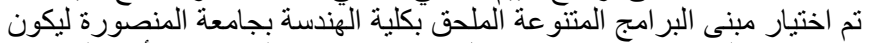

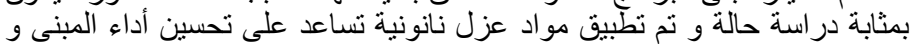
تقليل الطاقة المستهلكة خاصة في عمليات التبريد. 